\title{
Performance Evaluation on Low-Crest Breakwater at North Coast of Java Island
}

\author{
Parlindungan Sudrajat Simanjuntak \\ Board of Kalimantan I River Basin, Ministry of Public Works, Pontianak, INDONESIA \\ Alx201184@gmail.com
}

\begin{abstract}
Low-crest breakwater is one of coastal safety structures that used in managing the erosion at along the coast. As a newly studied and used coastal safety structure in Indonesia, the use of the structure requires an evaluation of whether its application is succeeded or not. Therefore, evaluation regarding on the utilization of coastal safety structure in form of low-crest breakwater was conducted. The research was to be conducted in locations that have low-crest breakwater structures, which is Pekalongan City, Demak Regency, and Jepara Regency. The research was conducted by using primary data in form of direct observation on location of implementation; and secondary data in form of tidal, wave, and coast material data. These data were expected to be able to provide a depiction on whether the low-crest breakwater structure application in Pekalongan City, Demak Regency, and Jepara Regency are succeeded. The observation in the implementation area showed positive result in the form of coast sedimentation in Pekalongan City and Demak Regency; although structural damage occurred in the Jepara Regency location. The matters that related to this condition were structure material and coast utilization. The material of the structured use geotextile with 5 to 7 years usage time - in which damage would develop when in direct contact with human or if there's sharp material towards the coast. In the case of coast utilization activities, such as boat mooring or fishing, geotextile material best not to be installed, or other stronger material should be chosen for it.
\end{abstract}

Keywords: Low-Crest Breakwater; coastal safety; North Coast of Java; breakwater

\section{INTRODUCTION}

Application of low-crest breakwater structure has been vastly used in the developing countries, yet this structure was one of the coastal safeties that just newly studied by the Ministry of Public Works in 2009, and was being installed as a test run in Pasir Puth Anyer Beach, West Coast of Banten Province, on 2010. Lowcrest breakwater as one of man-made coastal safety has similar function with coastal safety in general but has an advantage in terms of more environmentally-safe and able to maintain the aesthetic of the beach itself.

As an evaluation of its effectiveness, installation test of low-crest breakwater was conducted in several locations in North Coast of Java, as a follow-up from prototype testing in Pasir Putih Anyer Beach. Some of the locations were including the Tanjung Kait Beach in Tangerang and Pisangan Beach in Karawang; it was with hope that the installation would have same success such as in Pasir Putih Anyer Beach. However, because of the installations is still new, the effectiveness and success of the low-crest breakwater certainly must be researched whether it can provide the expected results.

The formulation of the problem that was about to be studied is on the performance of the low-crest breakwater structure that was newly built in 2010, which its benefit on North Coast of Java needed to be reviewed, particularly on the research locations of Pekalongan City, Demak Regency, and Jepara Regency; whilst also studying on what parameters most affecting to the performance of low-crest breakwater structure on the field. The research was intended to evaluate the low-crest breakwater performance in the mitigation management on North Coast of Java, with study cases of Pekalongan City, Jepara Regency, and Demak Regency.

\section{LITERATURE REVIEW}

\subsection{Transformation of Waves at Approaching the Beach}

The propagation of waves when approaching the beach undergoes several changes because of influence from the water depth, the shape of the beach profile, and of course, the character of the waves itself. The forms of change that could occur are refraction, diffraction, and reflection.

Figure 1 shows that with the installation of the breakwater construction, the process is still taking place. Diffraction would bend at around the obstacle end and would enter the sheltered region behind it, in direction of perpendicular propagation. Reflection collides directly to the construction, and become a fully or partially reflection depends on its construction types, 
permeable or impermeable. Propagation of the wave energy would occur on the breakwater construction, the wave would move toward the beach with direction of wave height change into smaller or shielded, which also known as the process of diffraction.

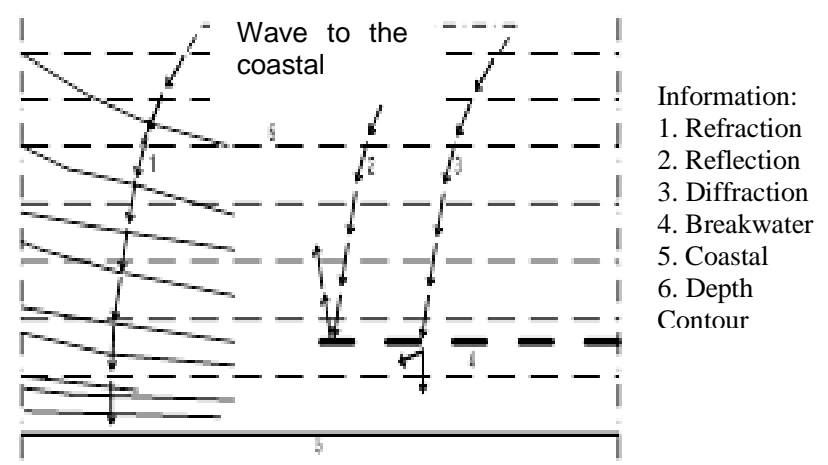

Figure 1. Refraction, diffraction, and reflection on the breakwater

\subsection{Break Wave}

The waves from deep-ocean that goes toward the beach are experiencing changes. The changes are shown in the shape of the waves, in which the crest is increasingly sharp, the trough is increasingly flat, also the increasingly reduced speed and the wavelengths.

The comparison between wave height and wave length in the form of the tilt are affecting the break wave. If the wave goes to shallow sea, the boundary slope depends on the relative depth $d / L$ and seabed slope $m$.

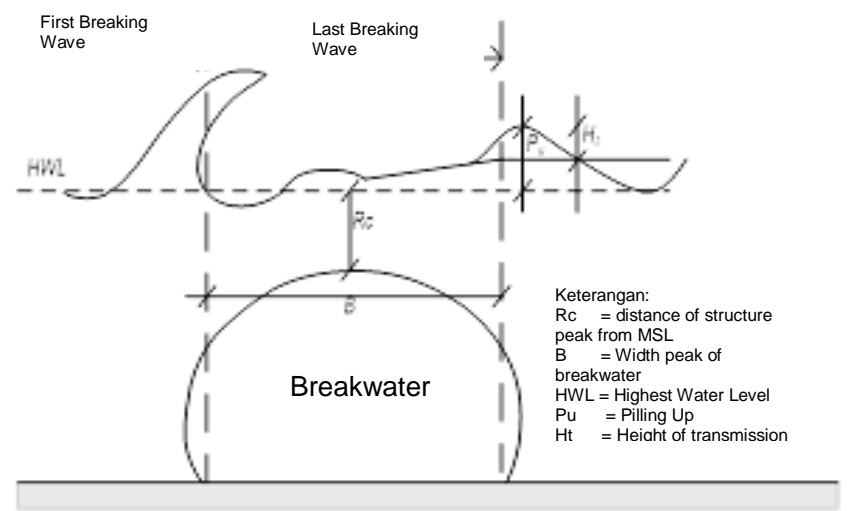

Figure 2. Break wave on low-crest breakwater (Water Resources Research and Development Center, 2015)

Figure 2 shows the break wave on the low-crest breakwater structure construction. The structure of low-crest breakwater is constructed in a way so that the waves that pass through the structure top are forced to break and dissipate its energy.

\subsection{Tide}

Tide is the result of sea levels fluctuation due to attractive force of sky objects, which are the sun and the moon; particularly the moon, because of its closer distance to earth. The height of tide is vertical distance between high water and low water that are in sequence with water surface rising period which is called high tide, and low tide for the decrease of sea water level. The turning point (slack) is the reversed current between high tide current and low tide current. Turning point can happen at water surface at its highest and water surface at its lowest, and the current velocity is zero.

Sea surface elevation that changes all the time requires a fixed elevation based on the tidal data. The elevations are as follows (Yuwono, 2016):

\section{HAT (Highest Astronomical Tide) \\ 2. HHWS (Higher High Water Spring) \\ 3. MHWS (Mean High Water Spring) \\ 4. MSL (Mean Sea Level) \\ 5. MLWS (Mean Low Water Spring) \\ 6. LLWS (Lower Low Water Spring) \\ 7. LAT (Lowest Astronomical Tide)}

\subsection{Coastal Sediment Transport}

Coastal sediment is caused by the transports that formed caused by the waves and currents. The sediment is the result that came from river or sea itself; if there is a cliff on the coast, then the sediment can also form from the scouring of the cliff. The sediment supply caused by wave amount is of course not the same with the sediment that came from the river.

Sediment transport on the coast is affected by decrease in depth and increase in wave height. The velocity increase near the bed causes a stronger sedimentation movement, which then causes ripple-in form of seabed small wave with vertical peak on the wave direction. The forming of the ripple would increase turbulence and lifting of the sediment in form of suspension-which is also known as suspension transport. If the water movement is becoming stronger, the ripple will dissipate and a mass transport will occur - in form of layer with certain thickness that lifted in form of sedimentation transport.

Sediment transport on low-crest breakwater is only an offshore-onshore transport, in which the formed sediment comes from the beach that is perpendicular to the sea (Figure 3). But the low-crest breakwater with gap has another advantage than the conventional breakwater, whereas the sediment transport does not depend on tidal cycle and takes place continuously. This is because the installation of low-crest breakwater 
structure is in MSL condition, which causes sediment transport does not depend on high tide condition.

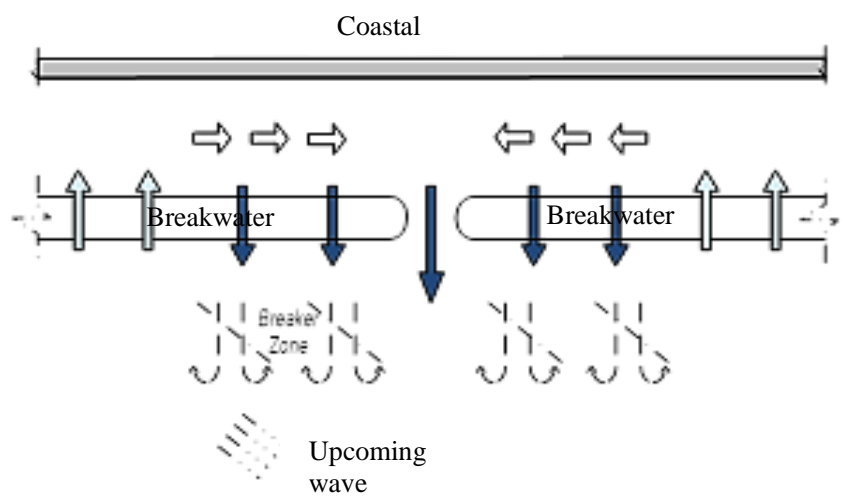

Figure 3. Sediment transport on low-crest breakwater (Water Resources Research and Development Center, 2015)

\subsection{Coastal Damage and Its Security Efforts}

On total length of Indonesian coast at 99,000 km, there are about twenty percent of damage recorded, which caused by environmental change and coastal erosion.

Coastal erosion is a natural phenomenon in which the coast's natural defense could not withstand the invading incoming waves, thus the coast could be eroded. After the large wave subsided, the coast would return to its former form with the effect from normal waves; yet there are times that the eroded coast could not return to its form because the materials that shape the coast are transported into other places and do not return to its original location. Therefore, the coast has suffered from erosion (Triatmodjo, 2012).

Other conditions that cause erosion is man-made damages, in form of mangrove logging and coral reef mining - whereas both are the natural protections of a coast. The change in land use, industrial polluting, and mining that human carried out also cause damages to these natural protections.

Coast utilization that nowadays established by the community, such as salt mining area, tidal agricultural zone, tourism object, and industrial area, have made the coastal area into a very important area for daily life. In this case, if a coastal area is not protected, the damages would occur uncontrollably.

Coastal protection is intended to handle the existing erosion on the coast that suffers from shoreline retreat. The first thing to do is to find what causes the erosion, then to determine the appropriate way to handle it. There are several ways to protect the beach, such as (Triatmodjo, 2012): a) Strengthening/protecting the coast so it could withstand the invading waves,

b) Changing sediment transport rates along the coast,

c) Reduce the energy of the wave that reaches the shore,

d) Add sedimentation supply to the beach or the ones that eroded.

Erosion management is adjusted to the existing environmental condition in the eroded location; the categories of erosion management are by natural and artificial management. Natural management is usually geographically supported, such as utilization of sand dunes, sands, mangrove utilization and Nipa palm in muddy beaches, or beaches with corals that could withstand charging waves.

In general, natural coastal management could be done if geographical support is in place. Natural management such as mangrove utilization still could be conducted even if the material is not available in the location - if it is geographically supported, the material still could be procured. However, it still needs to be supported with condition of muddy beach, which could support the life ability of the mangrove-type plants. At another natural management effort, sand dunes usually exist in beaches with spills from volcano materials. This is clearly seen on Parangtritis Beach in Yogyakarta, which has Mount Merapi as its supporter; without similar supply, the sand dunes would not be formed.

Geographical advantage is sometimes not obtained in a beach area; therefore it is required artificial management as an option. Artificial reinforcement on beach could be in form of reinforcement by additional structure on beach, stabilization construction, and beach restoration.

Low-crest breakwater is a type of artificial reinforcement, in the form of a stabilization construction that is similar to conventional breakwater. Similar to common breakwater, low-crest breakwater is intended to weaken the wave energy, holding sedimentation transport, and to form salient. The difference of using low-crest breakwater lies in the placement of the peak that is close to or slightly appears above the average sea level.

Optimal installation of low-crest breakwater is depicted in Figure 4 in which the low-crest breakwater could create a minimum water rise and does not create undesirable current, such as rip current. One of the problems in installation the low-crest breakwater with gap is the rip current, which could potentially erode sedimentation behind the coast structure. This could also disrupt the performance of the structure. 
The design of low-crest breakwater is to reduce or prevent coastal erosion, and to boost sediment accumulation so that new beach would be formed. An effective placement of the low-crest breakwater installation is by placing the structure on MSL (Mean Sea Level) position, or below the highest water level.

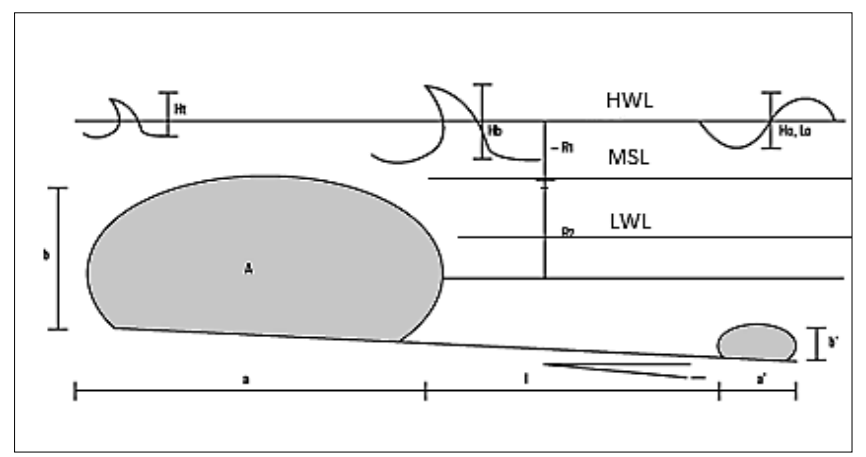

Figure 4. Placement of the summit of low-crest breakwater on MSL position low-crest breakwater application on coast

The main material that commonly used in low-crest breakwater structure is geotextile, which is an artificial product made from polymer material that is fabricated from a knitted or woven fabric sheet.

Basic details of the geotextile material are on the fiber type and the fiber fusion type. Geotextile itself has two category types, which are woven, with large pores and more-organized woven fibers; and non-woven, with very small pores and unorganized or unwoven fibers. This geotextile material is glued, heated, or sewed on its side, to be formed into tube, and then filled with mixture.

Geotextile is used because its characteristics which are flexible, permeable, fairly economical price, environmentally friendly, and the convenience to obtain. Filling materials on geotextile could be in form of several materials, such as non-cohesive soil like sands or muds, and in several cases where higher structural rigidity is needed, cement could also be used. The common utilization for geotextile material in coastal erosion management is in geotube with various types, such as geobag and geocontainer; the usage of these terms is highly varied, but it has the same purpose, which is geotextile could be filled with natural materials.

Appropriate selection on low-crest breakwater structure must fulfill several requirements, which are the double lock stitch type, with thread that has specification of seawater-proof, no connection, and the basic materials are polypropylene, polyester, and polyamide. The requirements and determined standards in choosing the appropriate geotextile are shown in Table 1.
Table 1. Geotextile Parameters for Low-crest Breakwater

\begin{tabular}{|c|c|c|}
\hline Parameter & Testing Method & Unit \\
\hline \multirow{4}{*}{ Tensile } & ASTM D 4595 & \multirow{3}{*}{$\mathrm{N} / \mathrm{m}$} \\
\hline & ISO $10319: 2008$ & \\
\hline & RSNI M-05-2005 & \\
\hline & ASTM D 4595 & \multirow{3}{*}{$\%$} \\
\hline \multirow[t]{2}{*}{ Elongation } & ISO $10319: 2008$ & \\
\hline & RSNI M-05-2005 & \\
\hline \multirow[t]{2}{*}{ Puncture } & $\begin{array}{l}\text { ASTM D } 6241 \\
\text { ISO } 12236 \cdot 2006\end{array}$ & \multirow[t]{2}{*}{$\mathrm{N}$} \\
\hline & ASTM D 4884 & \\
\hline \multirow[t]{2}{*}{ Seam } & ISO $10321: 2008$ & \multirow[t]{2}{*}{$\mathrm{N} / \mathrm{m}$} \\
\hline & RSNI M-03-2005 & \\
\hline \multicolumn{3}{|l|}{ Apparent } \\
\hline \multirow[t]{2}{*}{$\begin{array}{l}\text { Opening Size } \\
\text { (AOS) }\end{array}$} & ASTM D 4751 & \multirow[t]{2}{*}{$\mathrm{mm}$} \\
\hline & ASTM D 4491 & \\
\hline \multirow[t]{2}{*}{ Flow Rate } & ISO 11058:1999 & \multirow[t]{2}{*}{ Liter/minute/m2 } \\
\hline & SNI 08-4334-1996 & \\
\hline Endurance on & ASTM D 4886 & \multirow{2}{*}{$\%$} \\
\hline Abrasion & ISO $13427: 1998$ & \\
\hline Endurance on & ASTM D 4355 & \multirow{2}{*}{$\%$} \\
\hline UV & ASTM D 5970 & \\
\hline
\end{tabular}

Determination of the threshold distance for low-crest breakwater is based on submergence, which is ratio between water depths to height of the low-crest breakwater structure. There are three points that could be noticed, which are submergence degree in form of threshold distance $R_{c}=h-d$, relative height of the structure $h / d$, and ratio between threshold distance to the water depth $R_{d} / d$.

Estimation of the low-crest breakwater structure is based on several values, which are structure height $h$, water depth $d$, and difference between elevation of the structure's peak and elevation of the average water level $R_{c}=h-d$, which is the threshold distance, as shown in Figure 5. On the visible peak part, if the peak exceeds the water depth, the ratio is less than one; and in nondimensional drawing, to determine the submergence degree and the structure's peak, the one used is relative height of the structure $h / d$.

Submergence degree is connected with value on threshold distance, in which it is positive if it protrudes, and vice versa. Therefore, threshold distance is also called as submergence degree. To determine relative threshold distance, ratio between submergence degree and water depth could also be used:

$\frac{R c}{d}=\frac{(h-d)}{d}=\frac{h}{d}-1$ 


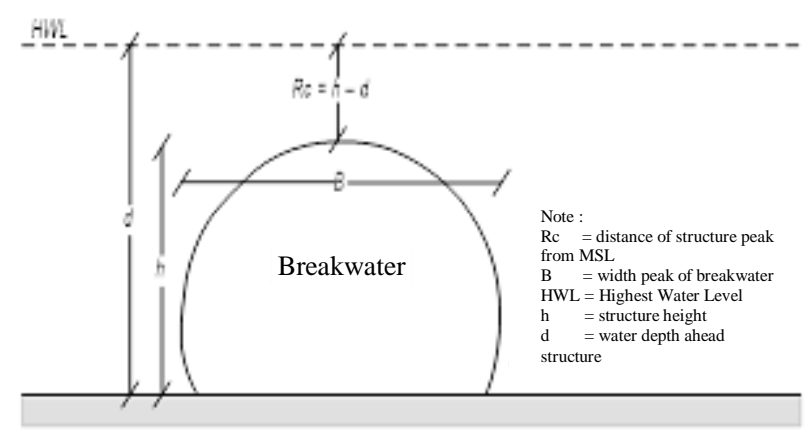

Figure 5. Geometrical parameter on low-crest breakwater structure (Sulaiman, et al., 2015)

To determine the placement of the low-crest breakwater is by calculating the low-crest breakwater distance from the shoreline, with the water depth taken when the structure is completely submerged, the length of the low-crest breakwater and the gap distance. If low-crest breakwater is installed more than one, the morphology of the beach behind it would be altered, with the formation of salient or tombolo.

Distance of low-crest breakwater from the shoreline is obtained from the location reference, which is the boundary condition of low-crest breakwater. In the reference, the placement of low-crest breakwater from shoreline is determined by comparing the depth of the location with the tilt of the beach, in which it relation is expressed by:

$\cot \varnothing=\frac{x}{h_{s}}$

Salient and tombolo would be formed if:

$\frac{L_{s}}{x}<\frac{1}{1-K_{t}}$

Salient on low-crest breakwater with gap would be formed if:

$\frac{G_{x}}{L^{2}}>0,5\left(1-K_{t}\right)$

With requirement of gap width:

$L \leq G \leq 0.8 L_{s}$

in which $\Phi$ denotes each slope, $x$ is low-crest breakwater distance from shoreline, $h_{s}$ is water depth in low-crest breakwater location, $K_{t}$ is wave transmission coefficient at MSL, $G$ is gap width, $a_{w}$ is amplitude of designated wave, $R c$ is distance of structure peak from MSL, and $T_{d}$ is period of designated wave

\section{RESEARCH METHOD}

Research was to be conducted by using three parameters, as follows:

\subsection{Coast condition and changes in shoreline}

At this stage, research was to be conducted visually by data collecting directly to the location field and through previous report data. The type of data that was about to be taken are:

a) Coast utilization by the community

b) Environmental condition of the coast with installation of low-crest breakwater structure, and

c) Shoreline problems on the installation location of the low-crest breakwater structure

\subsection{Construction structure}

At this stage, research was to be conducted by using two ways, which are using secondary data from central/local government, in form of planning data and implementation drawing. Next is visual data, which is by data collecting directly to the location field. The types of data taken are:

a) Review of the structure at the main material part of the construction structure,

b) Protection on construction and foundation

\subsection{Water condition}

Conditions of water that were to be studied in this stage are:

a) Waves data, through the data taken from Meteorological and Maritime Agency Class II Semarang. The data length that was used is data for 10 years, from 2007 up to 2016. Data waves recording was assumed to represent the waves recording on the research location. The data was classified in direction and velocity, which were divided into 8 compass points, and distribution of every velocity and wind direction were calculated and drawn in form of wave rose.

b) Research on coast material by taking sample from location field, and testing of the coast material through laboratory testing.

\section{RESEARCH RESULT}

\subsection{Pekalongan City Coast}

Installations of low-crest breakwater structure in Pekalongan City were located in four locations as can be seen in Figure 6, the Sari Beach of $\pm 1650 \mathrm{~m}$, Mangrove Park Beach of $\pm 835 \mathrm{~m}$, Slamaran Tourist Beach of $\pm 410 \mathrm{~m}$, and Landfills Slamaran Beach of \pm $975 \mathrm{~m}$. The development of coastal safety structure by low-crest breakwater was on 2011 up to 2015 . 


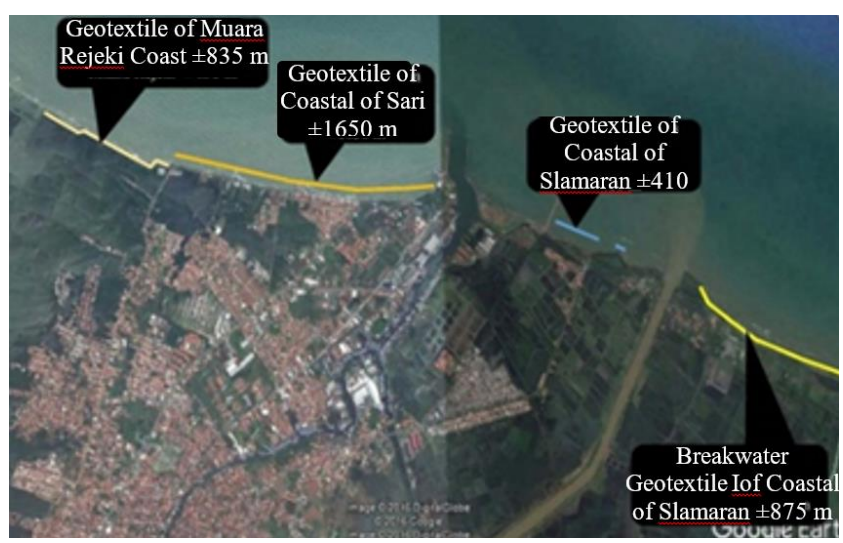

Figure 6. Location of low-crest breakwater implementation on Pekalongan City.

\subsubsection{Construction Structure}

Coastal safety structure was installed with scouring protection on depth of $\pm 0.50 \mathrm{~m}$, with two types of structure, ones with geobag material that was installed on along the shoreline, and the other one that was with geotube geotextile that was installed on $\pm 20 \mathrm{~m}$ offshore at depth of MSL. On the Sari Beach and Slamaran Tourism Beach, the coastal safety was installed with geotube, while on Mangrove Park Beach and Landfill Slamaran Beach, it was installed with two types of coastal safety (Figure 7): the geobag and the geotube. Type of geotube installed was per material with width of $20 \mathrm{~m}$ and height of $1.5 \mathrm{~m}$. Geobag was installed on two types, first one was with width of $4.40 \mathrm{~m}$ and height of $1.35 \mathrm{~m}$, and second one was with width of $5.50 \mathrm{~m}$ and height of $1.80 \mathrm{~m}$.

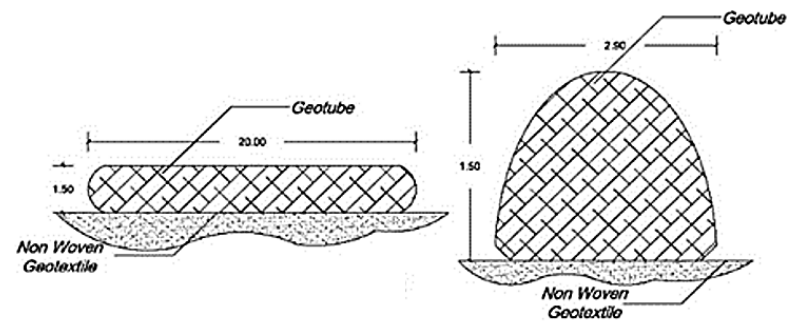

Geotube Longitudinal Section Geotube Transversal Section

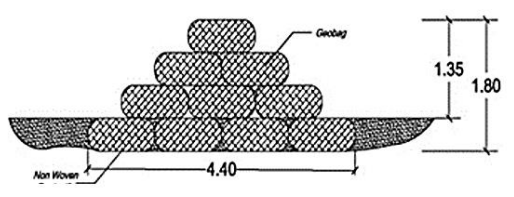

Geobag Transversal Section Type 1

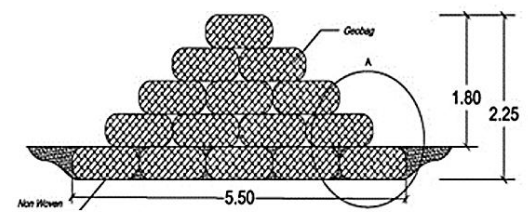

Geobag Transversal Section Type 2

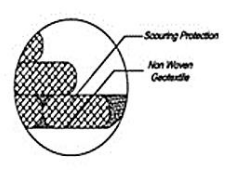

Detail A

Figure 7. Low-crest Breakwater Construction Structure in Pekalongan City.

\subsubsection{Coastal Conditions of Pekalongan City}

Summary of coastal condition can be seen in Table 2 . This data is used for design of the low-crest breakwater.

Table 2. Coastal conditions in Pekalongan Regency

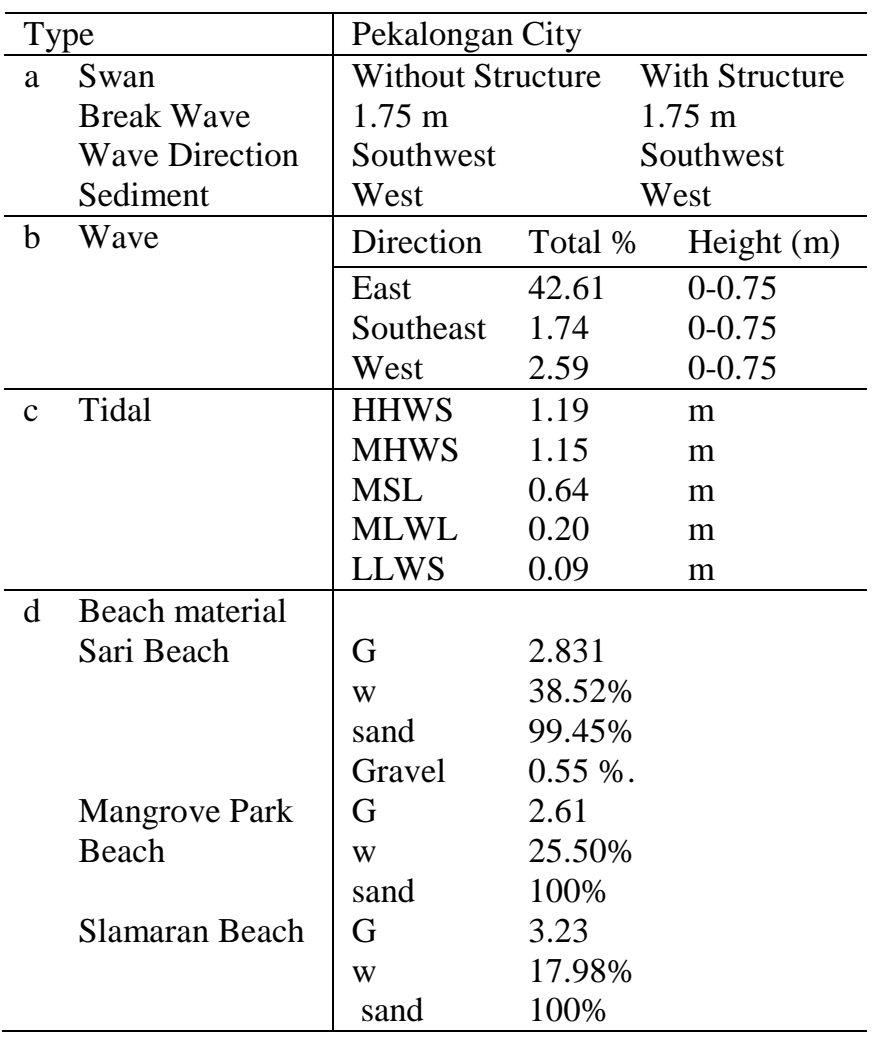

\subsubsection{Beach Conditions and Shoreline Change}

Before low-crest breakwater was installed, the beach suffered from erosion and coastal flood that threaten settlement condition around the coast (HuMa, 2006); even though construction of coastal safety has been conducted, such as with seawall, groin, and masonry. After the coastal safety construction used the low-crest breakwater structure, condition of the beach has got several changes, such as beach growth by sedimentation presence in the location where the structure was installed. The view of Pekalongan Beach in 2017 is shown in Figure 8.

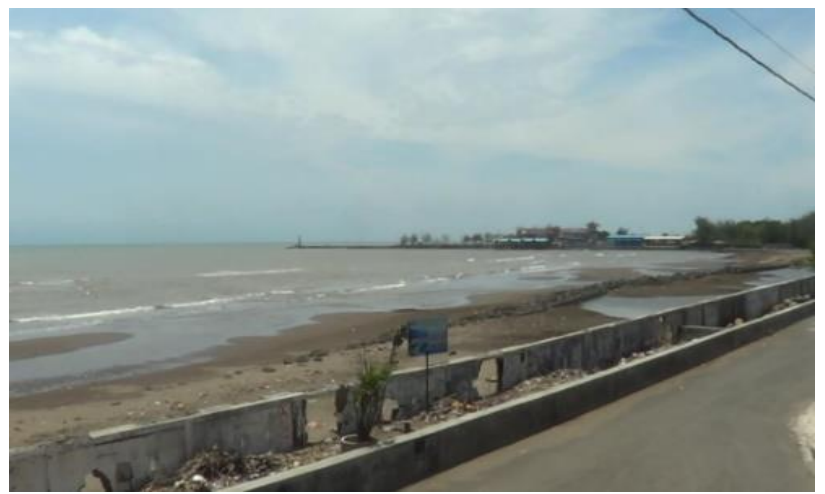

Figure 8. Conditions of Pekalongan Beach in 2017. 


\subsubsection{Performance Evaluation on Low-crest Breakwater on Pekalongan City}

Erosion management in Pekalongan City Beach by using low-crest breakwater structure generally showed a positive result, by beach growth of 15 to 20 meters; however, Slamaran Tourism Beach generally has not shown a positive result; it's evident from the yet absence of new beach development in form of beach growth. Further evaluation of this condition should be conducted because other locations on Pekalongan coast already have new beach growth.

This structure was located at 15 to 20 meters distance from the beach, therefore there was no significant damage made by beach visitors. On low-crest breakwater structure with geobag mounted along the beach, repairment and monitoring are necessary, because several damages that occurred, such as sand loss, that could create further destruction. Low-crest breakwater structure with geotube was located on location far from visitors and tourists, but monitoring needs to be conducted on the damages.

Water conditions show the average waves of Pekalongan City is in the category of low waves, with dominant waves that move in Pekalongan City coast come from northwest, north, northeast, and east on dry season and rainy season. The tidal condition in Pekalongan City on installation of low-crest breakwater in MSL showed that the height of tidal wave could help the sedimentation process. The analysis result from software SWAN showed that although installation of low-crest breakwater reduces the wave height, the incoming wave that still arrives at the structure would help the sediment transport process.

In general, erosion along the Slamaran Beach could be handled with low-crest breakwater installation, yet it could not be used for coastal flood. This is because the low-crest breakwater was installed in the MSL position. Other coast management effort should be used to handle coastal flood.

\subsection{Demak Regency Coast}

Installation of low-crest breakwater structure in Demak Regency was located in Sayung Sub-district, Sriwulan Village as shown in Figure 9. There were two types of low-crest breakwater structure installation, which are the Hybrid Low-crest Breakwater structure on 2015 of $\pm 195 \mathrm{~m}$ and Geobag low-crest breakwater with bamboo pole in 2016 of $\pm 80 \mathrm{~m}$. Both of the low-crest breakwater structure types were installed in MSL.

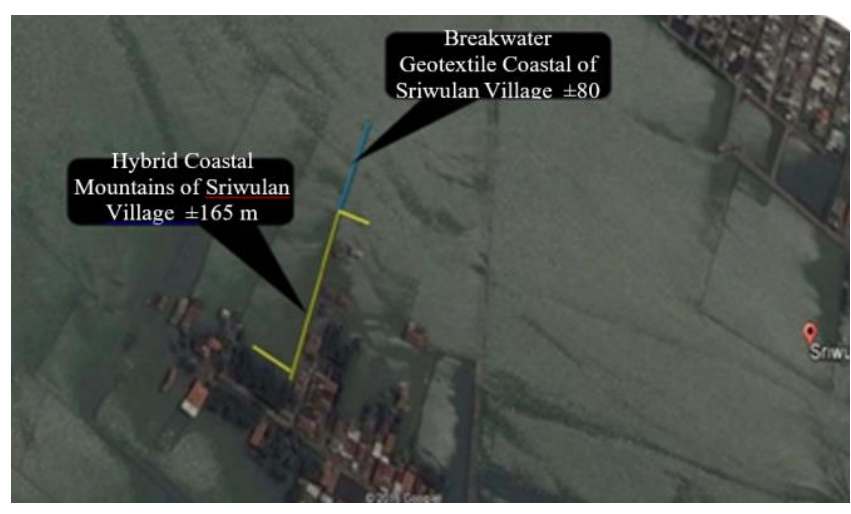

Figure 9. Location of Low-crest Breakwater Implementation in Demak Regency

\subsubsection{Construction Structure}

Installation of low-crest breakwater in Demak Regency used two different structures. The Hybrid Low-crest Breakwater was installed with bamboo reinforcement, with bamboo length of 4 meter, distance between bamboo of $50 \mathrm{~cm}$, and width of $1 \mathrm{~m}$ (Figure 10).
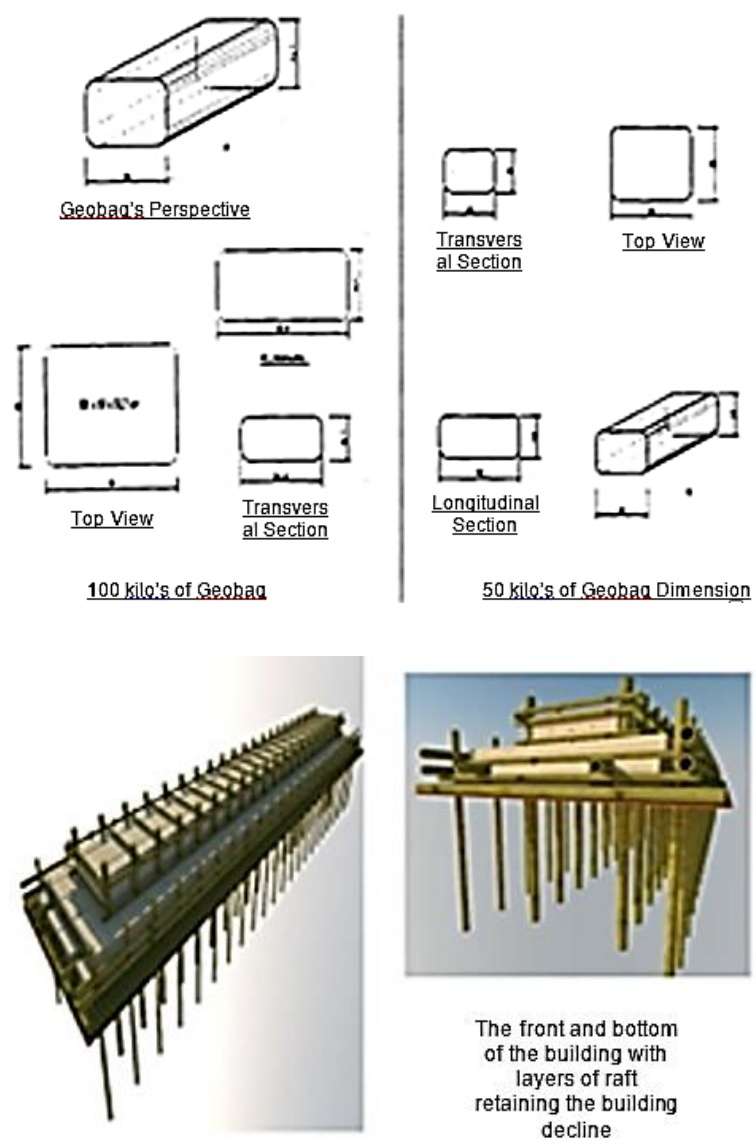

Top View of Soft Bamboo Soil Wall Building

Figure 10. Detailed Drawing on Low-crest breakwater on Demak Regency

Reinforcement of rope and bamboo crosswise as reinforcement between bamboos, and low-crest breakwater materials was using rock with $10 / 15 \mathrm{~cm}$ of 
size as its filler. On structure of geobag low-crest breakwater with bamboo pole, bamboo was used in wide position as the foundation reinforcement, and scouring protection was installed with $50 \mathrm{~cm}$ distance between bamboo, and in the longitudinal side, bamboo was installed with $50 \mathrm{~cm}$ of distance between bamboo for as long as $80 \mathrm{~m}$ on both side. The length of one bamboo foundation was $4.50 \mathrm{~m}$ with depth of the stake was $2.50 \mathrm{~m}$.

\subsubsection{Coastal Conditions of Demak Regency Coast}

Summary of coastal condition in Demak Regency can be seen in Table 3. This data is used for design of the low-crest breakwater.

Table 3. Coastal conditions in Demak Regency

\begin{tabular}{|c|c|c|c|c|c|}
\hline & Type & \multicolumn{4}{|c|}{ Demak Regency } \\
\hline \multirow[t]{4}{*}{$\mathrm{a}$} & \multirow{4}{*}{$\begin{array}{l}\text { Swan } \\
\text { Break Wave } \\
\text { Wave Direction } \\
\text { Sediment }\end{array}$} & \multicolumn{2}{|c|}{ Without Structure } & \multicolumn{2}{|c|}{ With Structure } \\
\hline & & \multirow{3}{*}{\multicolumn{2}{|c|}{$\begin{array}{l}2 \mathrm{~m} \\
\text { Southeast } \\
\text { East, Southeast }\end{array}$}} & \multirow{3}{*}{\multicolumn{2}{|c|}{$\begin{array}{l}2 \mathrm{~m} \\
\text { Southeast } \\
\text { East, Southeast }\end{array}$}} \\
\hline & & & & & \\
\hline & & & & & \\
\hline \multirow[t]{3}{*}{$\mathrm{b}$} & \multirow[t]{3}{*}{ Wave } & Direction & \multicolumn{2}{|c|}{ Total $\%$} & Height (m) \\
\hline & & Northeast & \multicolumn{2}{|c|}{16.52} & $0-0.75$ \\
\hline & & East & \multicolumn{2}{|c|}{46.96} & $0-0.75$ \\
\hline \multirow{3}{*}{$\mathrm{c}$} & \multirow{3}{*}{ Tidal (m) } & HHWS & \multicolumn{2}{|c|}{120.59} & $\mathrm{~cm}$ \\
\hline & & MSL & \multicolumn{2}{|c|}{59.90} & $\mathrm{~cm}$ \\
\hline & & LLWS & \multicolumn{2}{|l|}{0.79} & $\mathrm{~cm}$ \\
\hline \multirow{5}{*}{$\mathrm{d}$} & \multirow{5}{*}{ Beach Material } & $G$ & \multicolumn{2}{|l|}{2.52} & \\
\hline & & $\mathrm{w}$ & \multicolumn{3}{|c|}{$190.08 \%$} \\
\hline & & sand & \multicolumn{3}{|c|}{$44.28 \%$} \\
\hline & & Silt & \multicolumn{3}{|c|}{$31.68 \%$} \\
\hline & & clay & \multicolumn{3}{|c|}{$24.04 \%$} \\
\hline
\end{tabular}

\subsubsection{Beach Conditions and Shoreline Change}

Damages occur in Sriwulan Village Beach are coastal erosion and coastal flood, in which the land subsidence and rising sea level took place. The increasing number of ponds then damages the beach condition; also the illegal mangrove logging causes erosion and makes a faster destruction on beach in the location (KeSEMaTJURNAL, 2010).

On the location of geotextile geobag low-crest breakwater, there was presence of sedimentation or a beach growth since the installation in 2016; however this beach growth still could not solve the problem. This is because the installation that was only $\pm 80 \mathrm{~m}$ and coastal flood that is still happening.

Hybrid Low-crest Breakwater as shown in Figure 11 was installed on three positions, which are in front of the settlement, at side of the settlement, and at the mangrove plant protection. The observation on Hybrid Low-crest Breakwater showed that the best performance was the ones at the side of the settlement, in which it holds the coastal flood wave that goes directly to the settlement. There was no material filling on the Hybrid Low-crest Breakwater that was installed in front of the settlement, therefore it is not working; while several points of the installation on the mangrove plant protection were still not filled, therefore the protection does not run well and the mangroves are suffered from damages.

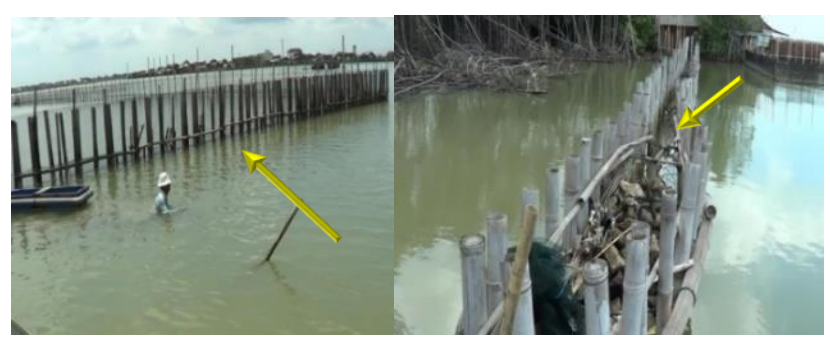

(a) Hybrid Low-crest Breakwater In Front of the Settlement and Mangrove Protection

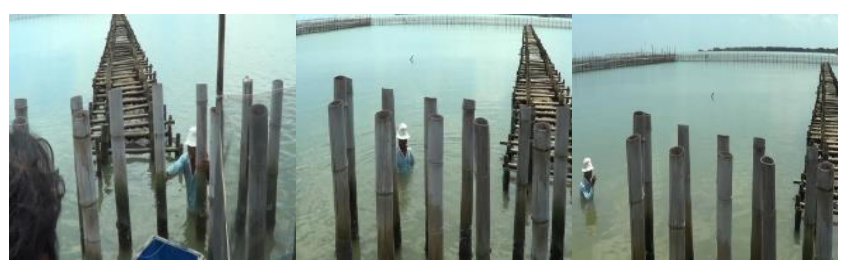

(b) Geobag Low-crest Breakwater with Bamboo Poles

Figure 11. Demak Regency Beach Conditions

\subsubsection{Performance Evaluation on Low-crest Breakwater on Demak Regency}

On its installation, the Hybrid Low-crest Breakwater has not shown the expected result. The Hybrid Lowcrest Breakwater installation has two functions, which are to protect the residents' settlement, and to protect the mangrove forest. The installation of Hybrid Lowcrest Breakwater with the intention of protecting residents' settlement has shown result, in which the coastal flood wave did not directly hit the settlement, although the coastal flood that occurred still inundate the residents' homes. As for Hybrid Low-crest Breakwater for mangrove forest protection, it was not maximal, since there are still several locations without filling. This then caused a less maximal performance from the Hybrid Low-crest Breakwater structure in protecting the mangrove plants. Further advanced management and monitoring on the location are needed; in order to make the structure could maximally perform, since the mangrove utilization could give added value in the existing protection.

In general, the erosion management in Sriwulan Village Beach, Demak Regency by using geobag lowcrest breakwater with bamboo has shown positive result, in which sedimentation has occurred in the location of the low-crest breakwater installation. The bamboo utilization as structure protection has gave added value for safety to the geobag material; whereas 
only relatively small damages occurred, in the form of declining position of the bamboo pole, which needs monitoring and repairment. Another repairment that could be conducted is cleaning the shells that are attached, so as not to cause further damage to the structure.

Water conditions show the average waves of Demak Regency is in the category of low waves, with dominant waves that come from northeast and east. The tidal condition in Demak Regency on installation of low-crest breakwater in MSL showed that the height of tidal wave could help the sedimentation process. The analysis result from software SWAN showed that although installation of low-crest breakwater reduces the wave height, the incoming wave that still arrives at the structure would help the sediment transport process.

Geobag low-crest breakwater with bamboo pole showed positive result in terms of sedimentation issue, yet not on the coastal flood-in which it still occurred. This is because the geobag low-crest breakwater with bamboo pole was installed in the MSL position. Other coast management effort should be used to handle coastal flood.

\subsection{Jepara Regency Coast}

Low-crest breakwater structure in Jepara Regency was installed in Bayuran Beach. Low-crest breakwater structure was installed $\pm 500 \mathrm{~m}$ along the shoreline (Figure 12).

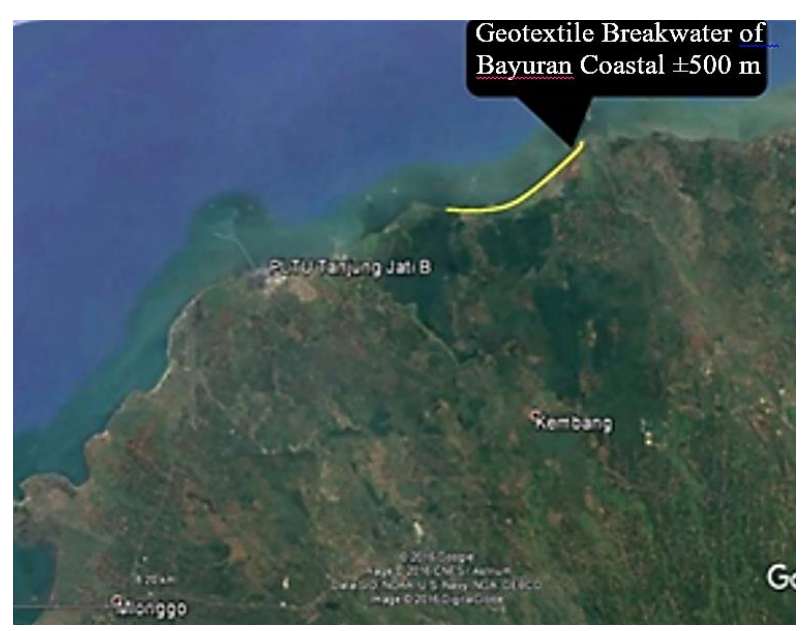

Figure 12. Location on Low-crest Breakwater Implementation on Jepara Regency

\subsubsection{Summary of Coastal Conditions in Jepara Regency}

Summary of coastal conditions in Jepara Regency shown in Table 4.
Table 4. Coastal conditions in Jepara Regency

\begin{tabular}{|c|c|c|c|c|}
\hline & & Jepara Regency & & \\
\hline $\mathrm{a}$ & Swan & Without Structure & $\mathrm{W}$ & ure \\
\hline & Break Wave & & & \\
\hline & Wave & $1.5 \mathrm{~m}$ & & heast \\
\hline & Direction & Southeast & $\mathrm{Ea}$ & \\
\hline & Sediment & East, Southeast & & neast \\
\hline $\mathrm{b}$ & Wave & Direction & Total \% & $\begin{array}{l}\text { Height } \\
\text { (m) }\end{array}$ \\
\hline & & East & 46.09 & $0-1.50$ \\
\hline & & Southwest & 3.48 & $0-1.50$ \\
\hline $\mathrm{c}$ & Tidal (m) & HHWS & 153.90 & $\mathrm{~cm}$ \\
\hline & & MSL & 94.50 & $\mathrm{~cm}$ \\
\hline & & LLWS & 35.10 & $\mathrm{~cm}$ \\
\hline 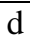 & Beach & $\mathrm{G}$ & 4.11 & \\
\hline & Material & w & $13.37 \%$ & \\
\hline & & sand & $100 \%$ & \\
\hline
\end{tabular}

\subsubsection{Construction Structure}

Figure 13 shows the material used in the low-crest breakwater construction which was non-woven geobag filled with local sands. Geobag was placed as high as 2 levels, with foundation digging of as deep as more or less $30 \mathrm{~cm}$, with average width of $2.40 \mathrm{~m}$, and height of about $1 \mathrm{~m}$. Reinforcement of non-woven geotextile material on lower layer as support was implemented in the lower part of the foundation.

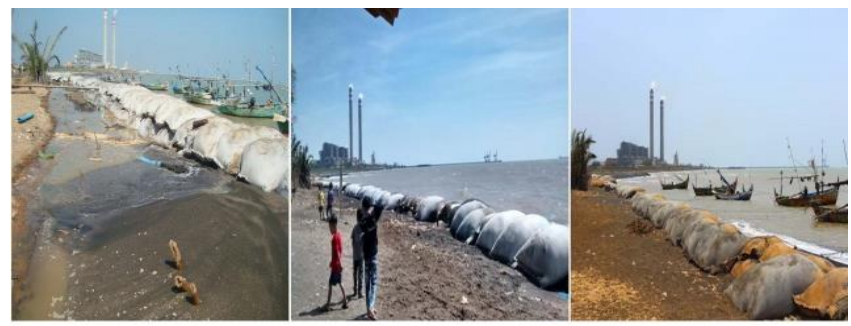

Figure 13. Construction of low-crest breakwater in Jepara Regency

\subsubsection{Beach Conditions and Shoreline Change}

The existing erosion condition in along the Bayuran Beach of Jepara Regency has shown destruction in form of shoreline retreat, which threatens the settlement area around the Bayuran Beach. The shoreline retreat in Bayuran Beach is 20 to 50 meters long. Related to the development of Steam Power Plant that was built since 2006, this has led to the increase of waves that move toward to Bayuran Beach. This is shown on the loss of sand delta that shaped like a small island, which was located 10 meters from the shore of Bayuran Beach (Jaringnews.com, 2103). 


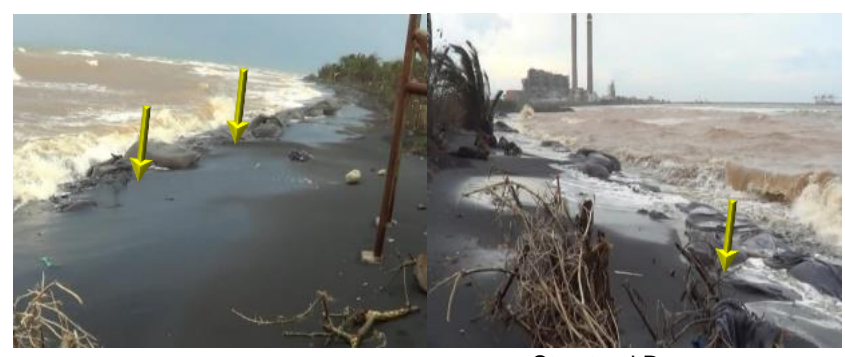

Structural Damage

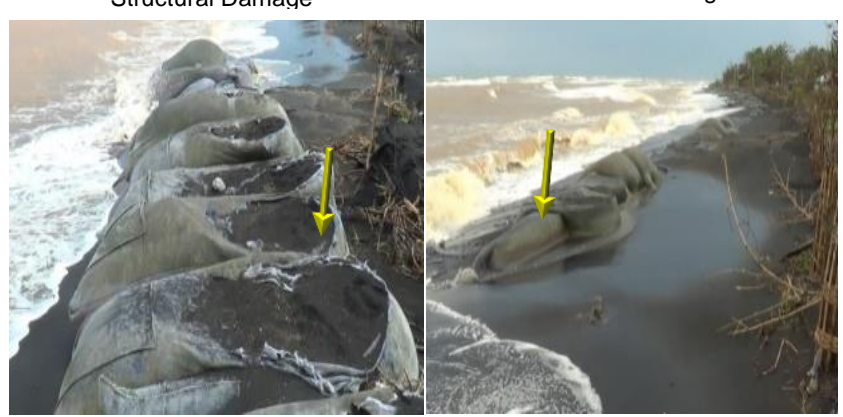

Structural Damage Reduced

Structural Damage

Figure 14. Structural damage of the low-crest breakwater structure on Jepara Regency

Based on the observation, low-crest breakwater installation on Bayuran Beach did not show the expected result, because of damages that occurred on the material and structure of the low-crest breakwater. The condition of the low-crest breakwater structural damage was shown in Figure 14, in which from the structure up to the foundation of the coastal safety structure suffered from damage.

\subsubsection{Performance Evaluation on Low-crest Breakwater on Jepara Regency}

Erosion management with low-crest breakwater structure along the shoreline of Bayuran Beach in Jepara Regency showed structural damages that were shown in almost all of the low-crest breakwater installation points. This then caused the expected result from the installation did not generate.

Water conditions show the average waves of Jepara Regency is in the category of low waves, with dominant waves that come from northwest, northeast, and east. The tidal condition in Jepara Regency on installation of low-crest breakwater in MSL showed that the height of tidal wave could help the sedimentation process. The analysis result from software SWAN showed that although installation of low-crest breakwater reduces the wave height, the incoming wave that still arrives at the structure would help the sediment transport process.

Damages on the low-crest breakwater structure on Jepara Regency could occur because of the low-crest breakwater material that is not in accordance with the condition on the field, in which a type of shell material that exists on the beach location could damage the lowcrest breakwater material. Another cause that could contribute to the damage is the placement of fishing boats on the location of the coastal safety structure. This is because the type of low-crest breakwater material, which was geotextile, is not a material that strong enough to resist the friction from the boats.

\section{CONCLUSIONS}

Conclusions that can be drawn from this study is are as follows:

a) Coastal safety using low-crest breakwater structure with non-woven geotextile material (material that is generally made from polyester (PET) or polypropylene (PP)) has usage time of around 5 to 7 years in its utilization to handle the erosion. This material is not as strong as construction with stone or concrete materials. The low-crest breakwater structures in Pekalongan City that were generally installed in 2012 are already showing damages in several parts, although they have a relatively strong geotextile material. The selection of geotextile material should also be in accordance with the beach condition; in which this discrepancy occurred in Jepara Regency, other than the geotextile material that looks incompatible, sharp shell materials are found, and boat moorings are also present in the installation location. Suitable structure installation was seen in the location of Sriwulan Village Beach in Demak Regency, in which the structure protection in form of bamboos pole could help to secure the structure.

b) For the necessity of coastal safety for the purpose of sedimentation and beach growth, the material that is good to be used in low-crest breakwater structure is geotube geotextile, which is more stable if it is installed on offshore. The necessity of coastal structure in form of reinforcement on the beach construction structure used the geobag geotextile that was implanted along the beach. Geobag could also be used as offshore structure, although by additional bamboo or wood as the reinforcement. Hybrid low-crest breakwater also could be used, but the need for stone material sometimes became an obstacle in the beach location.

c) Low-crest breakwater structure works better on muddy condition, in which mud deposition is faster than sands; this was seen on the installation of geobag low-crest breakwater with bamboo pole that was installed in 2016, wherein sedimentation that occurred in muddy beach in Demak Regency was faster than in the Pekalongan City with installation that was implemented in 2012. 
d) Damages on low-crest breakwater structure are generally caused by several cases. From the most frequent to rarely happen damages are vandalism, fishing boats, material that attaches to structure in form of shells, material that goes toward the beach or structure, and coast utilization by the community in form of pond. The worst damage is when the structure is left without protection and in direct contact with human, which are vandalism and fishing boat. Another type of damages in form of material that attaches and goes toward the structure could still be overcome by the structure or the geotextile material itself.

e) Coastal erosion management with coastal safety structure in form of low-crest breakwater is beneficial, but could not be used in managing the coastal flood that also occurs. This is because the installation of low-crest breakwater structure is in MSL (Mean Sea Level), therefore the runoff from the coastal flood could still happen.

\section{RECOMMENDATION}

The followings are recommendations considered necessary for further research:

a) In using the geotextile as the main material of lowcrest breakwater structure, it is needed to consider the thickness and the suitable fiber type as required in Indonesian National Standard or the water conditions, because of the many variations and types of the geotextile materials in order to provide the maximum structure strength.

b) Geotextile material has a relatively short usage time in its utilization as a part of structure to handle the erosion on the beach; therefore additional reinforcement in form of bamboo or wood is necessary. Other than that, advanced management on beach condition that has been repaired with mangrove planting is also necessary.

c) Geotextile material damages mostly when in direct contact with human. Other than that, a location in which boat or offshore water activities are present would greatly damage the structure material. Therefore, protection installation is needed, such as fence or warning sign to avoid possible destruction. d) Management on coastal flood that occurs in along the North Coast of Java could not be conducted by using the low-crest breakwater structure. To overcome this problem, other coastal safety structure needed to be installed, one example is in the form of seawall.

\section{REFERENCES}

$\begin{array}{lrrr}\text { HuMa, } & 2006 . & \text { Kompas. } & \text { [Online] } \\ \text { Available } & \text { at: } & \text { http://huma.or.id/wp- }\end{array}$ content/uploads/2006/05/Kompas-03-Februari-2006Abrasi-di-Kota-Tegal-dan-Pekalongan-Belum-

Teratasi.pdf

[Accessed 1305 2017].

Jaringnews.com, 2103. Abrasi Mengancam Pemukiman dan Sawah di Jepara. [Online] Available at: http://www.jaringnews.com/politikperistiwa/umum/50697/abrasi-mengancam-

pemukiman-dan-sawah-di-jepara

[Accessed 1405 2017].

KeSEMaTJURNAL, 2010. Kisah Tragis Desa Sri Wulan dan Cangkringan, Demak. [Online] Available at: https://kesematindonesia.wordpress.com $/ 2010 / 02 / 22 / \mathrm{k}$ isah-tragis-desa-sri-wulan-dan-cangkringan-demak/ [Accessed 1405 2017].

Sulaiman, D. M., Bachtiar, H., Taufiq, A. \& Hermanto, 2015. Beach Profile Changes Due to Low Crested Breakwaters at Sigandu Beach, Central Java. Chennai, Elsevier, pp. 510-519.

Triatmodjo, B., 2012. Perencanaan Bangunan Pantai. Yogyakarta: Beta Offset.

Water Resources Research and Development Center, 2015. Struktur Peredam Gelombang untuk Restorasi Tanaman Pelindung Pantai PEGAR Tanah Lunak, Buleleng: Balai Pantai.

Yuwono, N., 2016. Teknik Survey Hidrografi. Yogyakarta: PUSTRAL. 
[this page is intentionally left blank] 